\title{
Employment Dynamics of Australian Entrepreneurship: A Management Perspective
} Luke Hendrickson, Stan Bucifal, Antonio Balaguer, and David Hansell

\author{
" Entrepreneurs - the most successful, though not the") \\ only, practitioners of innovation - rarely stop to \\ examine how they do it. Most of them simply get on \\ with the job of creating value by exploiting some \\ form of change - be it in technology, materials, prices, \\ taxation, demographics, or even geopolitics."
}

\author{
Nicholas Valéry \\ In "Industry Gets Religion" \\ The Economist \\ February 18, 1999
}

\begin{abstract}
This article attempts to draw together the literature on high-growth firms and management capability using Australian Government data from the Expanded Analytical Business Longitudinal Database. We tracked cohorts of new micro-sized firms (startups) over five years from birth. Compared with startups that had a low employment growth trajectory, mediumand high-growth micro-startups exhibited higher financial performance, higher innovation activity, and a greater propensity to seek external (debt or equity) finance. From a management perspective, medium- and high-growth startups were also significantly more likely to monitor and assess their performance across a wider range of performance indicators. High-growth micro-startups exhibited significantly higher operational process and organizational/managerial innovation, a higher likelihood of foreign ownership, and a greater demand for equity finance than medium-growth micro-startups. This data is consistent with other evidence that suggests that sustained high growth comes from superior strategic management and may suggest an ongoing role for government policy in building firm management capability in order to foster employment growth.
\end{abstract}

\section{Introduction}

Creative destruction is a restructuring concept within an economy where it is argued that new, more innovative, and more productive firms replace less innovative, less productive ones (Schumpeter, 1942). The efficient reallocation of resources between these growing and shrinking firms is critical to aggregate employment and productivity growth. Empirical research has accelerated over the last few decades and appears to be validating the creative-destruction concept, at least from the employment-growth perspective. High-growth firms generate most of the jobs in an economy and tend to be younger than their non-high-growth counterparts (Moreno \& Coad, 2015). Large, persistent productivity differences between firms within industries is observed in all countries examined and productivity, driven in the long term by innovation, has repeatedly been shown to affect firm survival and growth (Mohnen \& Hall, 2013; Syverson, 2011). Considerable international evidence suggests that entry, exit, expansion, and contraction of firms are closely related to measures of innovation, productivity, and profitability (Bartelsman \& Doms, 2000; Foster et al., 2001; Moreno \& Coad, 2015; Syverson, 2011). Recent OECD results from 18 countries over the period 2001-2011 showed that young, small firms make a disproportionate contribution to job creation and that there are significant differences among countries in the capacity of these firms to survive and grow (Criscuolo et al., 2014). Hendrickson and colleagues (2015) confirmed that Australian firm employment dynamics are similar to that observed in other countries: between 2006 and 2011 startups (firms aged $0-2$ years) added approximately 1.44 million jobs to the 


\section{Employment Dynamics of Australian Entrepreneurship: A Management Perspective} Luke Hendrickson, Stan Bucifal, Antonio Balaguer, and David Hansell

Australian economy whereas all older firms (3+ years) shed just over 400,000 jobs over the same period. Understanding the motivations, entrepreneurial activities and framework conditions that drive these high-growth dynamics would therefore be expected to lead to better policy outcomes (see Aghion \& Roulet, 2014; Mason \& Brown, 2011; Nightingale \& Coad, 2013; Shane, 2009).

One explanation for the presence of high-growth, productive, and innovative firms is superior or strategic management capability (Moreno \& Coad, 2015). Through a combination of motivation, creativity, resources, and timing, a firm can opportunistically build or leverage a competitive advantage to achieve and sustain high growth (Bloom et al., 2013; Bloom \& van Reenen, 2010; Davidsson \& Wiklund, 2013; Foster et al., 2011). In Australia, strong management and leadership skills have been shown to be correlated with increased firm innovation, productivity, and growth, as well as overall increased employee engagement, satisfaction, and wellbeing (Boedker et al., 2011; Green, 2009). Recent empirical work by Bloom and colleagues (2014) suggests that one-quarter of cross-country and withincountry multifactor productivity gaps can be accounted for by management practices.

Innovation management is critical to business competitiveness (Dodgson, 2014). Studies of firms in the United Kingdom and Australia argued that innovation is a significant driver of firm growth with innovative firms growing two to five times faster than firms that do not innovate (Department of Industry, 2014; NESTA, 2009). Lentz and Mortensen (2008), working with a Danish firm panel from 1992-1997 found that $74 \%$ of aggregate productivity growth came from reallocation of employment to innovating firms through both entry/exit dynamics $(21 \%)$ and growth through capture of market share (53\%).

Until now, our capacity to understand these firm dynamics and its impact in Australia has been limited by a lack of integrated micro-aggregate data. This article outlines our recent efforts to bring the concepts of strategic management and employment growth dynamics closer together by determining whether strategic management characteristics are more common in high-growth Australian startups.

\section{Methodology and Results}

The Australian Department of Industry, Innovation and Science partnered with the Australian Bureau of Statistics (ABS) to create the Expanded Analytical Business
Longitudinal Database (EABLD; tinyurl.com/zncglzn). The EABLD is a census of firms over the period 2001 to 2012. Any firm with an Australian Business Number $(\mathrm{ABN})$ or Australian Company Number (ACN) is included. In 2001, there were 1.70 million firms in the database accounting for 7.12 million full-time equivalent jobs, $\$ 570$ billion value added, and $\$ 2.39$ trillion total sales output, of which $\$ 173$ billion came from exports. In 2012, there were 2.83 million firms in the database accounting for 8.96 million full-time equivalent jobs, $\$ 1.3$ trillion value added, and $\$ 4.48$ trillion total sales output, of which $\$ 352$ billion came from exports. The EABLD also includes a substantial number of firms (approximately 10,000 per annum) with detailed business characteristics. This information enabled us to cross-reference startup financial performance with firm business characteristics that relate to strategic management capability.

We followed five cohorts of micro-sized startups (i.e., fewer than 10 employees) over the five years following their entry into the economy (i.e., starting 2002, 2003, 2004,2005 , and 2006). We analyzed micro-startups as a representation of organic or de novo entrepreneurship, avoiding the influence of mergers/acquisitions by large firms influencing the result. After five years, we compare the financial performance of those surviving firms in the startup cohort that stayed in the same size range (0-9 employees) with those in the cohort that grew in employment into 10-19 and 20+ employee categories. In this article we label these latter firms as mediumand high-growth, respectively.

\section{Micro-startup financial performance}

Figure 1 shows that a very small fraction of the surviving micro-startups are responsible for most of the job creation by all micro-startups over a five-year period. Although representing only $3.2 \%$ of all micro-startups, they accounted for $77 \%$ of gross job creation by surviving micro-startups over five years. This result is very similar to results for other OECD countries (generally less than 5\%; Criscuolo et al., 2014). For most sectors of the economy, these firms grow dramatically after five years to more than compensate for the job destruction of exiting micro-startups.

Figure 2 shows that the disproportionate contribution of high growth micro-startups varies by industry (62.5\% to 93.6\%). For example, micro-sized mining firms that both survived and grew into a higher size class totalled $8.3 \%$ of all micro-entrants in that sector and also accounted for $93.6 \%$ of micro-firms' contribution to total employment growth for that sector. The 


\section{Employment Dynamics of Australian Entrepreneurship: A Management Perspective}

Luke Hendrickson, Stan Bucifal, Antonio Balaguer, and David Hansell

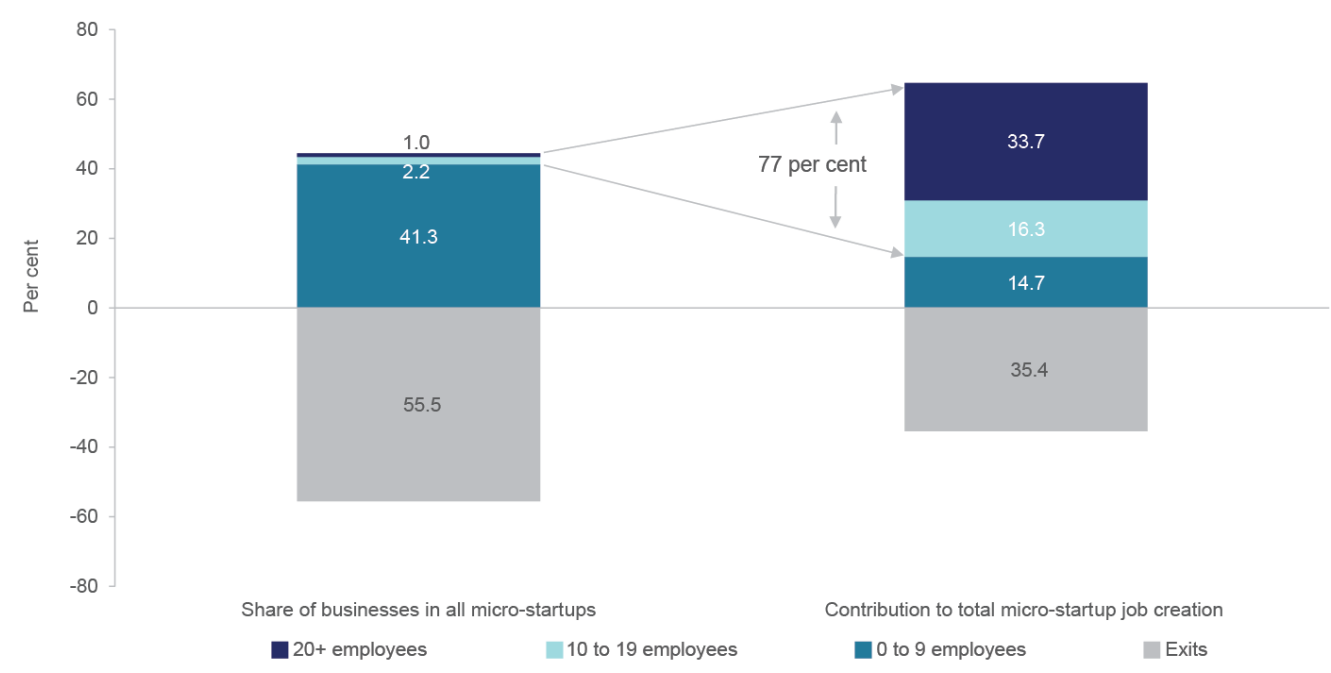

Figure 1. Five-year post-entry dynamics of micro-startups by share of firms for all sectors from 2002-2011. Source: Hendrickson et al. (2015).

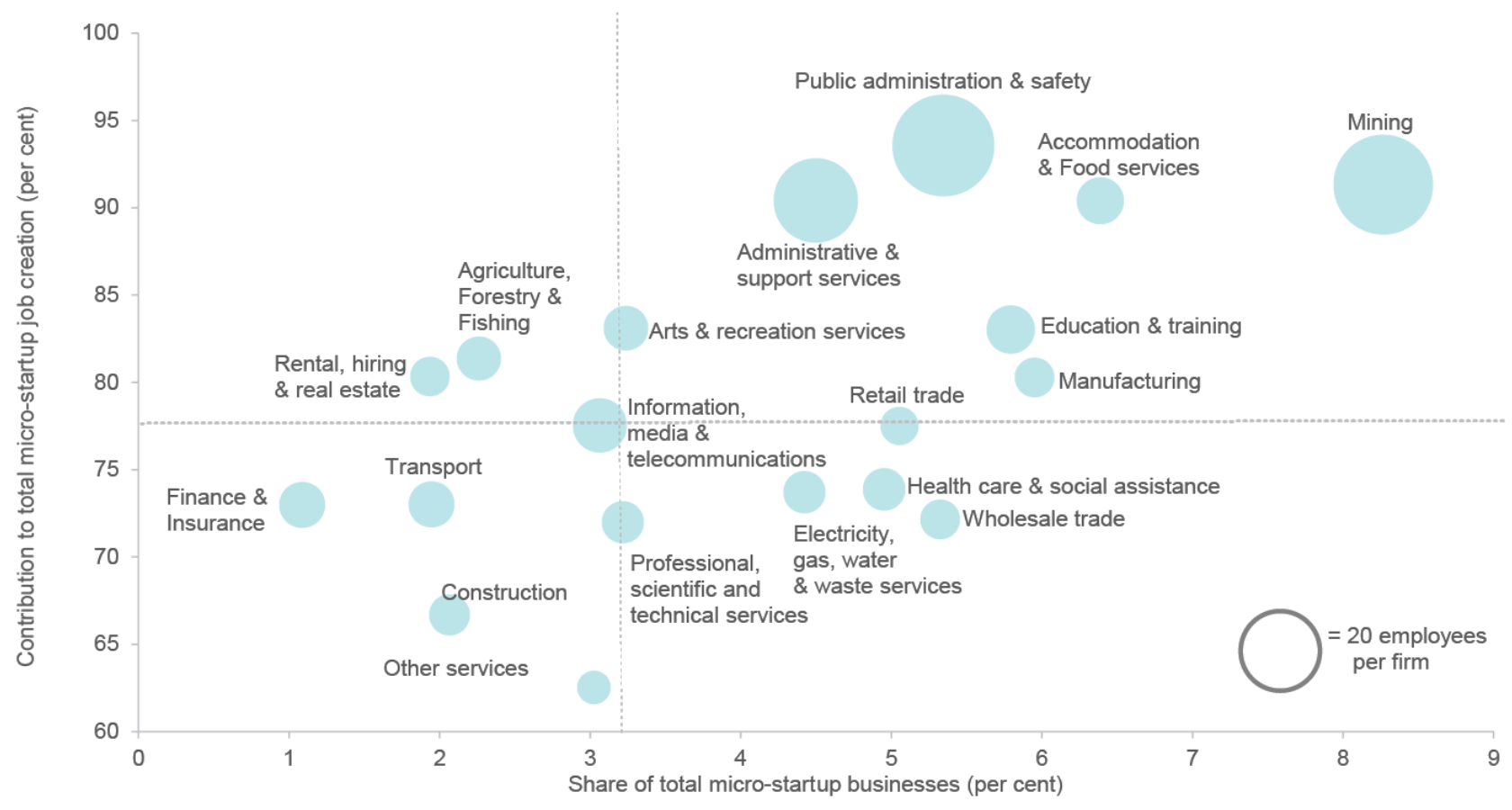

Figure 2. Five-year post-entry dynamics of micro-startups by share of firms, by industry from 2002-2011. The size of the bubbles represents the number of employees created per high-growth firm over five years.

Source: Hendrickson et al. (2015).

construction industry is at the other end of the spectrum with a lower percentage of high growth microstartups and, perhaps not surprisingly, a lower contribution to employment growth for the sector.

When we further analyzed the financial performance of medium- and high-growth micro-startups created in
2006 (aggregating all sectors), we found that these firms exhibited superior average sales, gross operating profit, employment, value added, and capital expenditure compared with surviving micro-startups firms that were stable or grew marginally over the same period (low-growth micro-startups). Figure 3 illustrates this trend for growth in sales for three sectors). Although 


\section{Employment Dynamics of Australian Entrepreneurship: A Management Perspective} Luke Hendrickson, Stan Bucifal, Antonio Balaguer, and David Hansell

the lower ranges on these performance measures were often similar, the upper ranges were significantly different. These results were common to all industry divisions in Australia and across earlier cohorts studied (data not shown).

Firms were asked the question: During the year, to what extent did the business focus on the following when assessing overall business performance? Figure 4 reports the percentage of firms that ticked "Major extent" for each of the six possible performance assessment categories. Figure 4 shows that the medium- and highgrowth micro-startups in our study were significantly more likely to assess their performance across a wider range of measures compared with their low-growth counterparts. High-growth micro-startups appeared to pay more attention to cost, financial, and operational measures of performance than their medium-growth counterparts (Figure 4). Medium- and high-growth micro-startups were significantly more likely to increase their range of goods and services offered, have some form of foreign ownership, and be seeking debt or equity finance over the first five years of their life (Fig- ure 5). Figure 6 shows the proportion of firms that reported introducing an innovation over a five period. Four different types of innovation are reported as defined by the OECD/Eurostat Oslo Manual (OECD, 2005). Figure 6 shows that medium- and high-growth micro-startups were significantly more likely to be innovating in any given year across the four main types of innovation: products, processes, organizational/management methods, and marketing methods. In particular, high-growth micro-startups exhibited significantly higher operational process and organizational/managerial innovation and double the likelihood of foreign ownership than medium-growth micro-startups (Figures 5 and 6).

\section{Conclusion}

Startup activity is critical for employment growth in Australia. It is a very small fraction (3\%) of surviving startups that go on to generate most $(77 \%)$ of the employment growth in young firms. These high-growth micro-startups occur in every industry sector of the economy. Job creation by these high-growth micro-

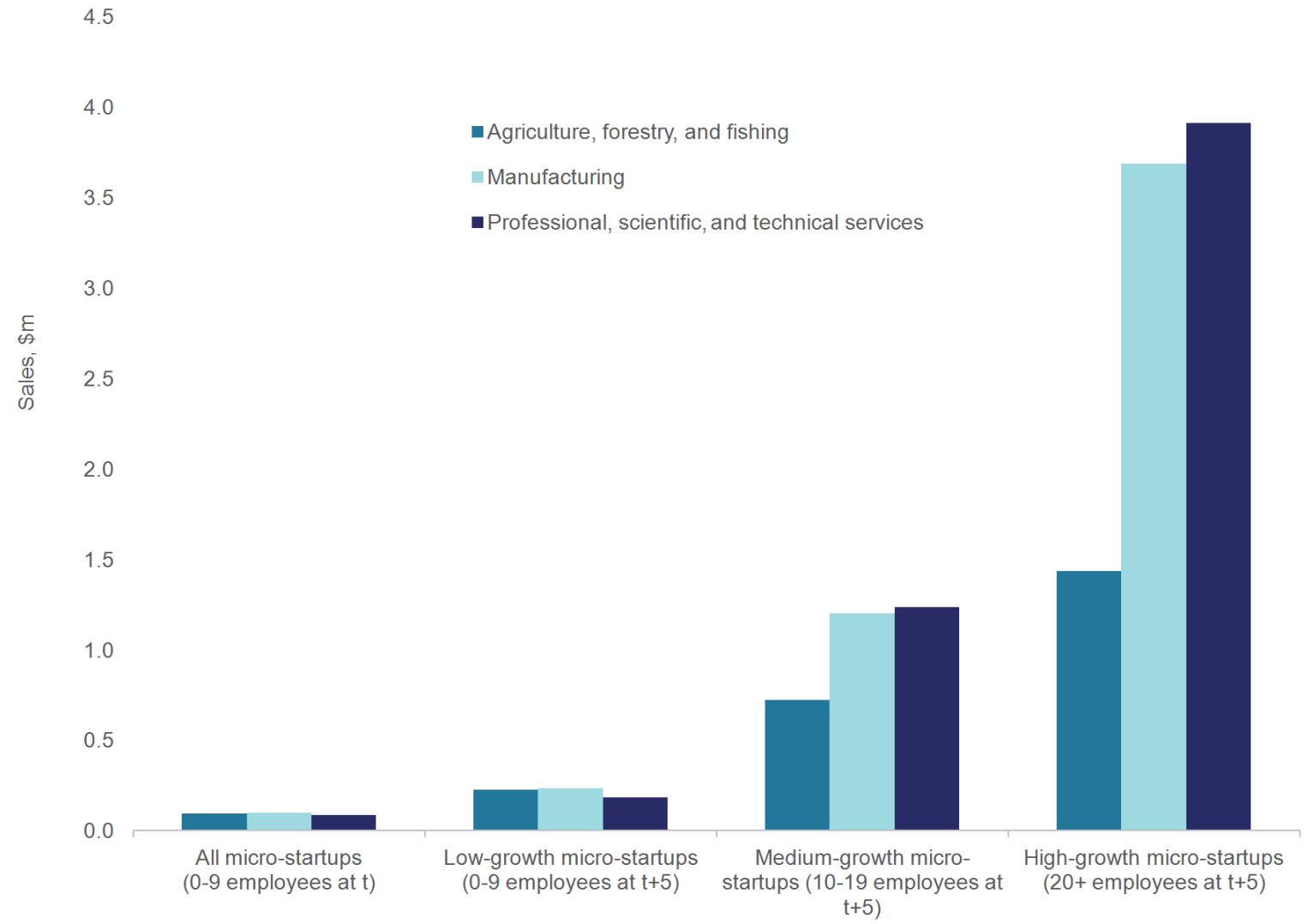

Figure 3. Mean sales at micro-startup stage and size class achieved after five years, by selected industry sector from 2006-2011. Source: Hendrickson et al. (2015). 


\section{Employment Dynamics of Australian Entrepreneurship: A Management Perspective} Luke Hendrickson, Stan Bucifal, Antonio Balaguer, and David Hansell

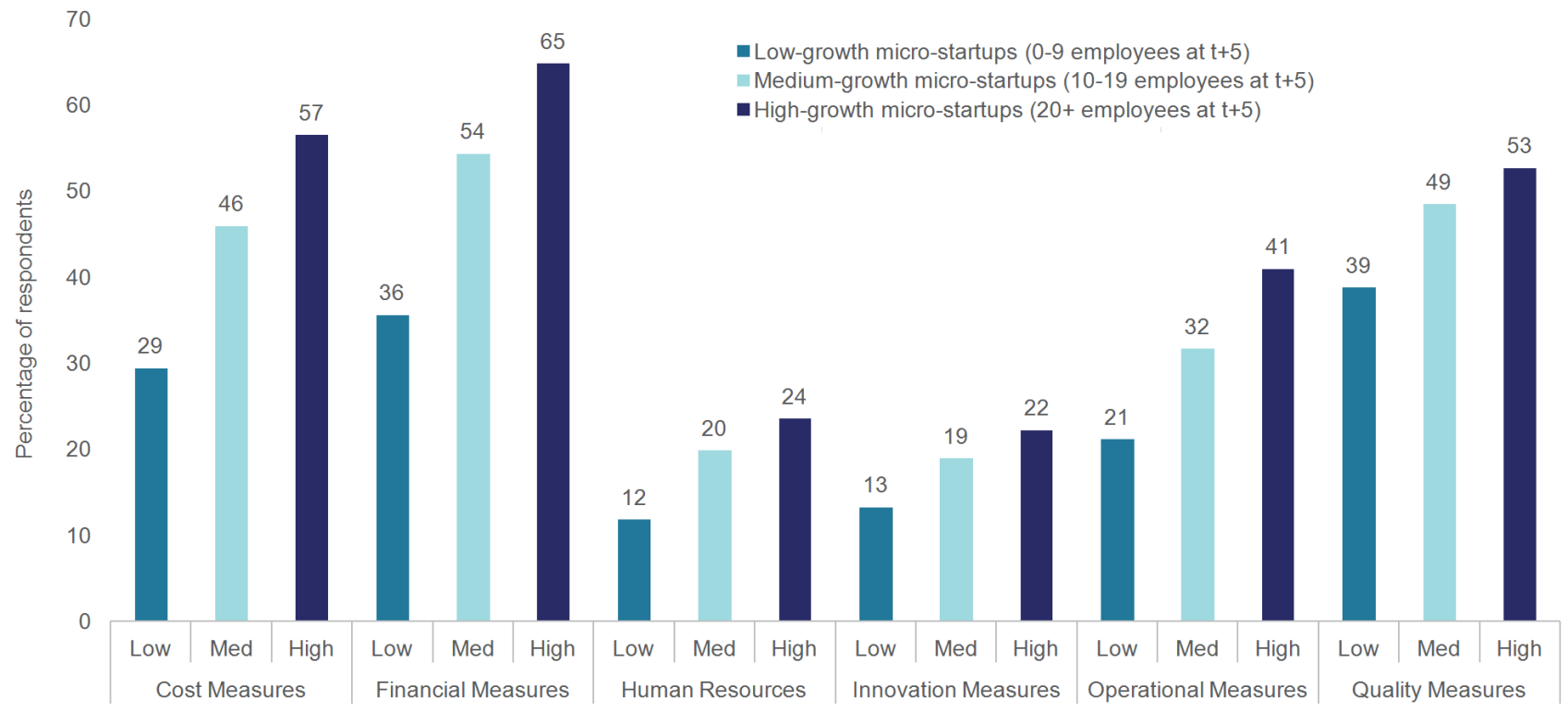

Figure 4. Startup business performance assessment, by five-year growth outcome (low, medium, high) from 2006-2011. Source: ABS (2015).

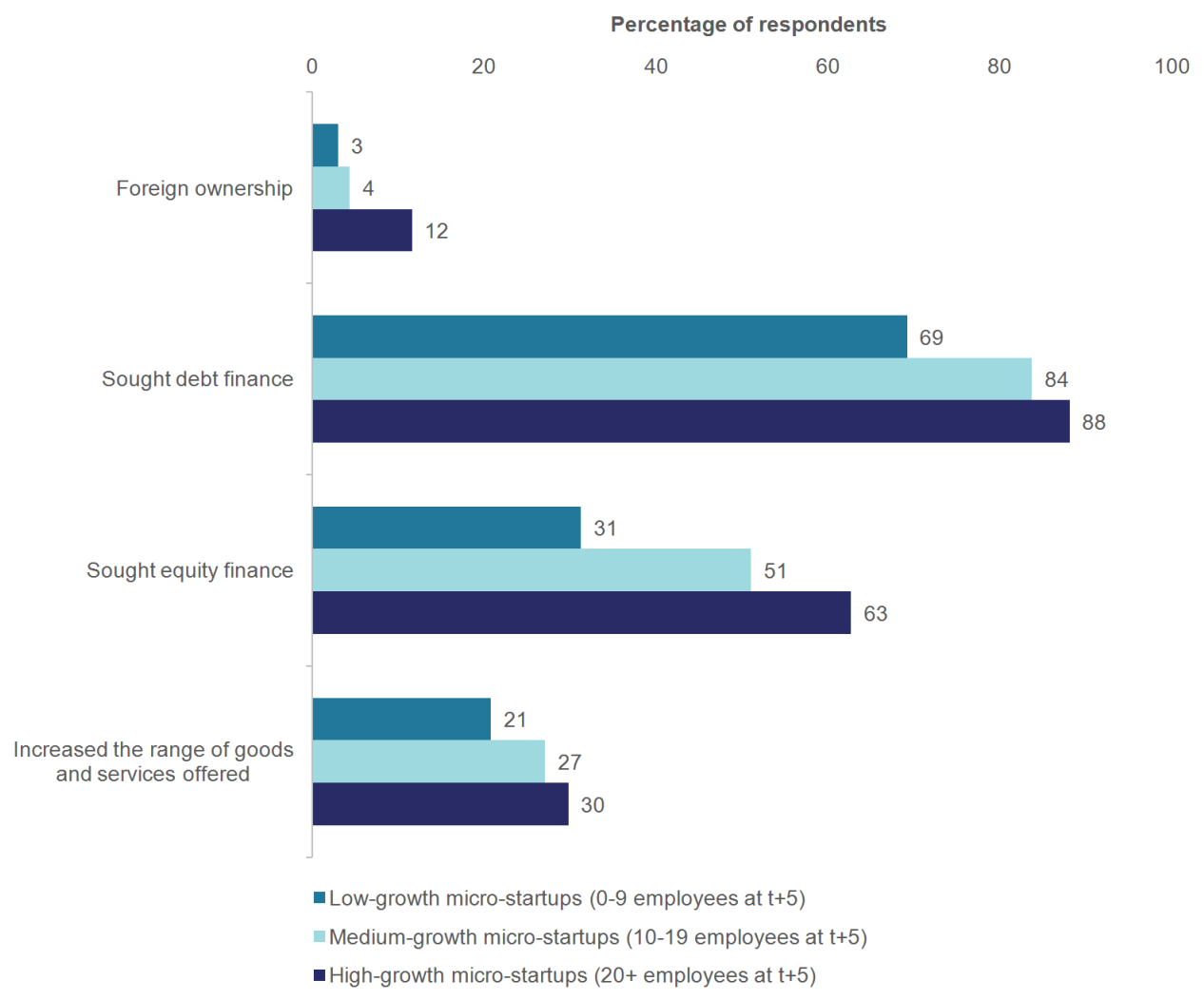

Figure 5. Mean percentage of startups reporting any foreign ownership, seeking of external finance, and annual increases in the range of goods and services offered by the firm, by five-year growth outcome from 2006-2011. Source: ABS (2015). 


\section{Employment Dynamics of Australian Entrepreneurship: A Management Perspective} Luke Hendrickson, Stan Bucifal, Antonio Balaguer, and David Hansell

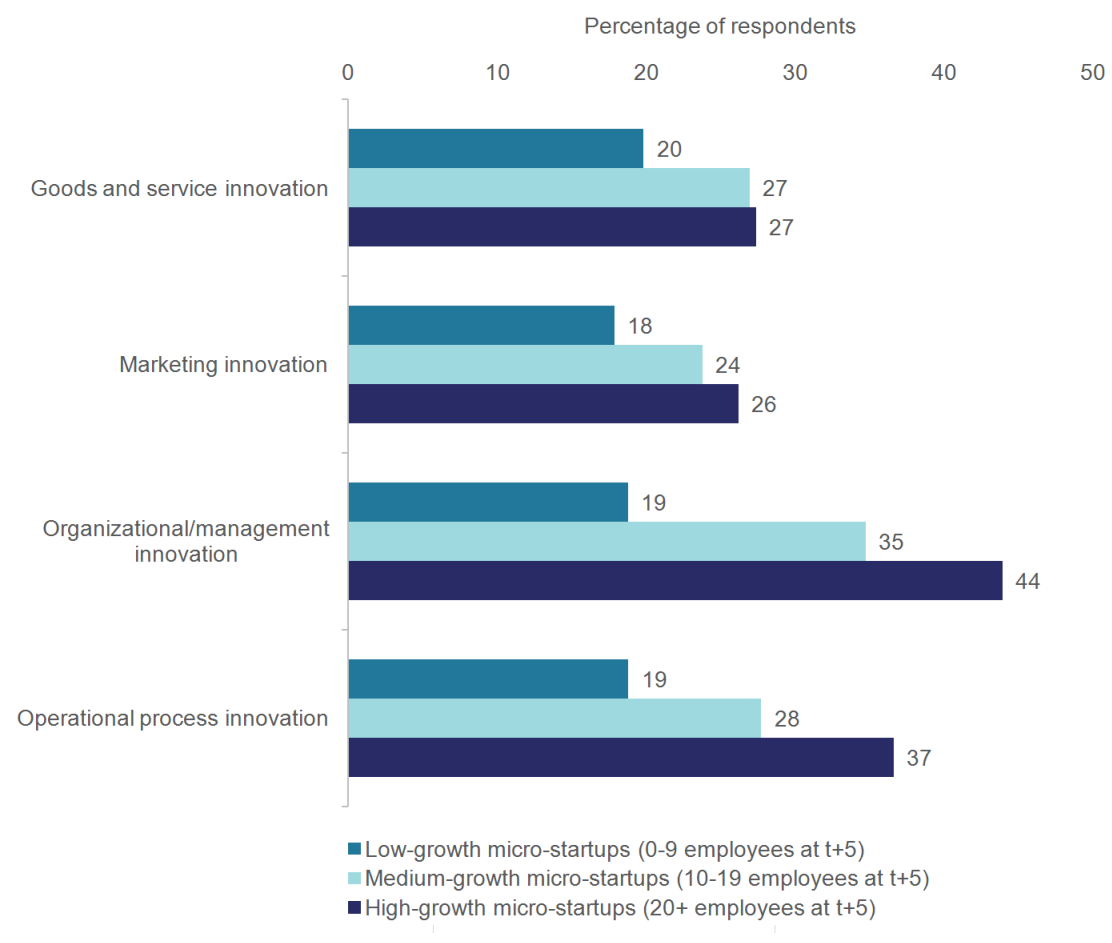

Figure 6. Mean innovation activity of low-, medium-, and high-growth micro-startups from 2006-2011.

Source: ABS (2015)

startups is more than enough to compensate for gross job destruction by exiting startups and downsizing mature firms. Our preliminary findings on the characteristics of Australian medium- and high-growth micro-startups confirms that these firms are significantly more innovative and more focused on performance assessment than lower-growth startups. We therefore suspect that our observed variation in financial performance and employment growth are, in part, explained by strategic decisions of startup management and leadership. Similar to the conclusions of Foster and colleagues (2011), we argue that high-growth startups are more likely to exhibit superior management are therefore are able to develop a sustained and unique market advantage, which in competitive markets is likely to come from investment in innovation (Davidsson et al., 2013; Fagerberg, 2013). Our data suggest that this innovation appears more likely to come in the form of new business models and processes rather than new goods or services.

Our findings have implications not only for firms themselves but potentially government policy: high-growth startup activity requires strong strategic management capability. The Australian Government has since 2008 run a management capability building initiative in its Entrepreneurs' Programme (tinyurl.com/hev6bc8) and recently introduced a "growth services" component, but it only supports established small and medium-sized enterprises (SMEs) in specific sectors. Our evidence also agrees with the OECD (2015a, 2015b) argument that equity finance is critical to high-growth startups. Unfortunately, Australia's venture capital industry appears to be focused on lower risk, later stage equity investments (Alinejad et al., 2015).

Our future research within the Department of Industry, Innovation and Science is broadening the scope of this study to determine the characteristics of high-growth firms of all ages using a more widely accepted definition of high growth (OECD, 2015b). We are also collaborating with the Australian Bureau of Statistics, the University of Technology Sydney, and Stanford University to assess the management capability of firms across Australia. The results from this work may further inform government policy as to whether Australia's firm management capability is an impediment to growth. 


\section{Employment Dynamics of Australian Entrepreneurship: A Management Perspective} Luke Hendrickson, Stan Bucifal, Antonio Balaguer, and David Hansell

\section{About the Authors}

Luke Hendrickson is Manager of Innovation Research in the Australian Government's Department of Industry, Innovation and Science, where he is focused on innovation and measuring the performance of the national innovation system. He is principally responsible for delivering the Government's annual Australian Innovation System Report (industry.gov.au/innovationreport), which is now in its seventh year. Luke's general work interests are in the areas of productivity and competitiveness and how innovative entrepreneurship drives these outcomes across all sectors of the economy. He also has a particular interest in the economics of complexity, measuring management capability, and business eco-innovation. Luke holds a $\mathrm{PhD}$ from the Australian National University in Canberra.

Stan Bucifal is a Researcher in the Australian Government's Department of Industry, Innovation and Science, where he works as a member of the Innovation Research team. His main research interests are in the field of industry policy, productivity, and innovation. He has experience in industry policy development, cost-benefit analysis applied to carbon emission abatement, and conducting research into intangible capital and the geography of innovation. Stan holds a Bachelor's degree in Business from the Queensland University of Technology, where he majored in Economics and Finance (QUT), and a Master's degree in Public Policy, specializing in industry strategy, from the Australian National University in Canberra.

Antonio Balaguer is a Researcher in the Australian Government's Department of Industry, Innovation and Science, where he works as a member of the Innovation Research team. His main research interests are in the fields of innovation, management, and technological change. Antonio was initially trained as chemist and holds a $\mathrm{PhD}$ in Political Economy and Asian Studies from Murdoch University in Perth, Australia, and a postgraduate diploma in Public Policy from the Australian National University in Canberra.
David Hansell is a Researcher with the Australian Bureau of Statistics, where he has worked since 2008. His main research interests include productivity of exiting and entering firms, and characteristics associated with high-productivity firms. David has an Honours degree in Asian history from the Australian National University in Canberra and a Masters of Economics degree from Macquarie University in Sydney.

\section{Recommended Reading}

- The Employment Dynamics of Australian Entrepreneurship (Hendrickson et al., 2015)

tinyurl.com/hpyoqoe

- Australian Innovation System Reports (Department of Industry, Innovation and Science, 2015) tinyurl.com/zsh4axm

\section{References}

Alinejad, M., Balaguer, A., \& Hendrickson, L. 2015. Financing Innovative Entrepreneurship. Canberra: Australian Government: Office of the Chief Economist, Department of Industry, Innovation and Science.

ABS. 2014. Counts of Australian Businesses, Cat. No. 8165.0. Canberra: Australian Bureau of Statistics (ABS).

ABS. 2015. Expanded Analytical Business Longitudinal Database 2001-02 to 2012-13. Canberra: Australian Bureau of Statistics (ABS).

Bartelsman, E. J. \& Doms, M. 2000. Understanding Productivity: Lessons from Longitudinal Microdata. Journal of Economic Literature, 38(3): 569-94.

http://www.jstor.org/stable/2565420

Bloom, N. \& van Reenen, J. 2010. Why Do Management Practices Differ across Firms and Countries? Journal of Economic Perspectives, 24(1): 203-24. http://dx.doi.org/10.1257/089533010797456229

Bloom, N., Lemos, R., Sadun, R., Scur, D., \& van Reenen, J. 2014. The New Empirical Economics of Management. NBER Working Paper 20102. Cambridge, MA: The National Bureau of Economic Research. http://dx.doi.org/10.3386/w20102 


\section{Employment Dynamics of Australian Entrepreneurship: A Management Perspective Luke Hendrickson, Stan Bucifal, Antonio Balaguer, and David Hansell}

Bloom, N., Brynjolfsson, E., Foster, L., Jarmin, R., Saporta-Eksten, I., \& van Reenen, J. 2013. Management in America. Discussion Paper 1301. Washington, DC: Center for Economic Studies. https://www2.census.gov/ces/wp/2013/CES-WP-13-01.pdf

Boedker, C., Vidgen, R., Meagher, K., Cogin, J., Mouritsen, J., \& Runnalls, J. M. 2011. Leadership, Culture and Management Practices of High Performing Workplaces in Australia: The High Performing Workplaces Index. Sydney: Society of Knowledge Economics.

Coad, A., Daunfeldt, S.-O., \& Halvarsson, D. 2015. Bursting into Life: Firm Growth and Growth Persistence by Age. Ratio Working Paper No. 264. Stockholm: The Ratio Institute. http://dx.doi.org/10.2139/ssrn.2616759

Criscuolo, C., Gal, P. N., \& Menon, C. 2014. The Dynamics of Employment Growth: New Evidence from 18 Ccountries. OECD Science, Technology and Industry Policy Papers No. 14. Paris: OECD Publishing.

http://dx.doi.org/10.1787/5jz417hj6hg6-en

Davidsson, P., \& Wiklund, J. 2013. Introduction. In P. Davidsson \& J. Wiklund (Eds.), New Perspectives on Firm Growth: 1-11. Cheltenham, UK: Edward Elgar.

Department of Industry. 2014. Australian Innovation System Report 2014. Canberra: Australian Government, Office of the Chief Economist.

http://www.industry.gov.au/innovationreport

Dodgson, M. 2014. Collaboration and Innovation Management. In M. Dodgson, D. M. Gann, \& N. Phillips (Eds), The Oxford Handbook of Innovation Management: 462-481. Oxford: Oxford University Press. http://dx.doi.org/10.1093/oxfordhb/9780199694945.013.003

Fagerberg, J. E. 2013. Innovation: A New Guide. TIK Working Papers on Innovation Studies No. 20131119. Oslo: Centre for Technology, Innovation and Culture (TiK), University of Oslo.

Foster, L., Haltiwanger, J. \& Krizan, C. J. 2001. Aggregate Productivity Growth: Lessons from Microeconomic Evidence. In C. R. Hulten, E. R. Dean, \& M. J. Harper (Eds.), New Developments in Productivity Analysis: 303-63. Chicago: University of Chicago Press.

Foster, G., Davila, A., Haemmig, M., He, X., Jia, N., von Bismarck, M., \& Wellman, K. 2011. Global Entrepreneurship and the Successful Growth Strategies of Early-Stage Companies. New York: World Economic Forum.

Green, R. 2009. Management Matters in Australia: Just How Productive Are We? Findings from the Australian Management Practices and Productivity Global Benchmarking Project. Canberra: Australian Government, Department of Innovation, Industry, Science and Research.

http://www.industry.gov.au/industry/OtherReportsandStudies/Do cuments/ManagementMattersinAustraliaReport.pdf
Hendrickson, L., Bucifal, S., Balaguer, A., \& Hansell, D. 2015. Employment Dynamics of Australian Entrepreneurship. Research Paper 4/2015. Canberra: Australian Government, Office of the Chief Scientist.

http://www.industry.gov.au/Office-of-the-Chief-

Economist/Research-Papers/Pages/The-employment-dynamicsof-Australian-entrepreneurship.aspx

Lentz, R., \& Mortensen, D. T. 2008. An Empirical Model of Growth through Product Innovation. Econometrica, 76(6): 1317-73. http://dx.doi.org/10.3982/ECTA5997

Mason, C., \& Brown, R. 2001. Creating Good Public Policy to Support High Growth Firms. Small Business Economics, 40(2): 211-225. http://dx.doi.org/10.1007/s11187-011-9369-9

Menon, C., Criscuolo, C., \& Calvino, G. 2015. DYNEMP V.2 Progress Report: Cross-Country Evidence on Start-up Dynamics. OECD Science, Technology and Industry Working Paper No. 2015/06. Paris: OECD. http://dx.doi.org/10.1787/5jrxtkb9mxtb-en

Mohnen, P., \& Hall, B. H. 2013. Innovation and Productivity: An Update. Eurasian Business Review, 3(1): 47-65. http://dx.doi.org/10.14208/BF03353817

NESTA. 2009. The Vital 6 Per Cent: How High-Growth Innovative Businesses Generate Prosperity and Jobs. London: NESTA.

Nyugen, T., \& Hansell, D. 2014. Firm Dynamics and Productivity Growth in Australian Manufacturing and Firm Services. Australian Bureau of Statistics Research Paper 1351.0.55.052. Canberra: Australian Bureau of Statistics (ABS).

OECD. 2005. Oslo Manual (3rd Edition). Paris: Organisation for Economic Co-operation and Development (OECD).

OECD. 2015a. OECD Innovation Strategy 2015. Paris: Organisation for Economic Co-operation and Development (OECD).

OECD. 2015b. Entrepreneurship at a Glance 2015. Paris: Organisation for Economic Co-operation and Development (OECD).

Senderovitz, M., Klyver, K., \& Steffens, P. 2015. Four Years On: Are the Gazelles Still Running? A Longitudinal Study of Firm Performance after a Period of Rapid Growth. International Small Business Journal, 34(4): 391-411.

http://dx.doi.org/10.1177/0266242614567483

Schumpeter, J. 1942. Capitalism, Socialism, and Democracy. New York: Harper \& Bros.

Shane, S. 2009. Why Encouraging More People to Become Entrepreneurs Is Bad Public Policy. Small Business Economics, 33(2): 141-149.

http://dx.doi.org/10.1007/s11187-009-9215-5

Syverson, C. 2011. What Determines Productivity? Journal of Economic Literature, 49(2): 326-365. http://dx.doi.org/10.1257/jel.49.2.326 